\title{
Molecular Divergence of Staphylococcus Aureus Isolated from Pork Byproducts Based on Coagulase Gene Polymorphism and The Presence of Enterotoxigenic genes
}

\author{
A. S. Hakim*, A.A.Samy, Sohad M. Dorgham, Shimaa T. Omara, E.A. Elgabry \\ Department of Microbiology and Immunology, National Research Centre, 33 Bohouth st., Dokki, Cairo, Egypt
}

\begin{abstract}
Background: Pork by-products are appeared to be a source of consumer coagulase positive S. aureus strains food poisoning.

Material and Methods: The genetic lineage of coagulase positive Staphylococcus aureus (coa) recovered from 20 imported and 30 locally manufactured pork byproducts in Cairo was checked using PCR, and restriction fragment length polymorphism analysis (RFLP).

Results: A total number of 27 S. aureus were isolated (54\%), the coa gene was identified in 17 out of that isolates (62.9\%) with molecular sizes ranging from $195 \mathrm{bp}$ to 1196bp. The coa RFLP analysis using BsuRI revealed 4 different band patterns related to the source of isolates. The detection of 7 enterotoxigenic strains out of the 27 S. aureus isolates suggested the public health importance.

Conclusion: There were different polymorphism patterns between local and imported isolates with the detection of enterotoxigenic genes represent a public health concern.
\end{abstract}

Keywords: Staphylococcus aureus - pork byproducts - coa gene - enterotoxins- RFLP.

\section{Introduction}

Staphylococcus aureus is a bacterium of critical significance, causing a variety of diseases in both animals and humans and its ability to resist different environmental forms [1]. S. aureus usually carry many virulence factors that include structural and secretory products which play importantrole in pathogenesis [2]. Coagulase is an extracellular protein that has generally been utilized to differentiate $S$. aureus from the less virulent staphylococci (Coagulase negative Staph- CNS) [3]. Two virulent factors were secreted by S. aureus, coagulase (coa) and von Willebrand element restricting protein (vWbp), both"coa" and "vWbp" together are required for the formation of abscesses and promote the non-proteolytic activation of prothrombin and cleavage of fibrinogen, reactions that are inhibited with specific antibodies against each of these molecules. "coa" specific antibodies confer protection against abscess formation and $S$. aureus lethal bacteremia.Therefore, coagulase may be used as vaccine antigens to elicit antibodies that protect against $S$. aureus infection [4]. Several molecular procedures have been usedfor identification and comparison of $S$. aureus isolates in epidemiological studies. Among these methods, coagulase gene (coa gene) typing which considered a simple and effective strategy for typing $S$. aureus into various subtypes [5].

Another concept of pathogenicity related to $S$. aureus is the ability of some strains produce the enterotoxins (SEs) which are considered a prime source of food intoxication that occurs after consumption of different foods, particularly ready to eat meat, contaminated with $S$. aureus either through unhygienic handling or later improper storage. (SEs) are strong gastrointestinal exotoxins produced by $S$. aureus during the phases of growth, they are resistant to heat treatment, acidity, and proteolytic enzymes, so keeping their effectiveness in the bowel after ingestion [6]. Pork and pork byproducts are supposed to be possible sources of SEs because pig skin is commonly colonized by S. aureus [7].

Following up the previous concepts, our study was conducted to cover the following points: Isolation and identification of $S$. aureus from local and imported pork by-products in Egyptian pork markets, molecular detection and polymorphism of coagulase gene (coa) from $S$. aureus isolates, besides molecular detection of major enterotoxin expressing genes.

\subsection{Sampling}

\section{Material And Methods}

A total of 50 samples (imported pork by-products, $n=20$ and local pork by-products, $n=30$ of three different manufacture factories). All samples were purchased between April and June 2016, from different pork markets in Cairo governorate, Egypt. The samples were transferred to the laboratory of microbiology in National Research Center, Giza in a container containing ice cubes under aseptic condition. 


\subsection{Isolation and identification of $S$. aureus}

Twenty gram samples were collected aseptically, 10-fold diluted with sterile quarter-strength Ringers Solution (Oxoid Ltd, London, UK) and homogenized for 90 seconds using the laboratory blender Stomacher 400 (Seward, London, UK). The cultures were incubated in $37^{\circ} \mathrm{C}$ for $24 \mathrm{~h}$. Then the samples were subcultured on Baird-Parker agar and incubated at $37^{\circ} \mathrm{C}$ for $24-48 \mathrm{~h}$. The presumptive colonies of S. aureus were identified by Gram stain, catalase, coagulase (both the slide and tube) and DNase tests [8,9]. The isolates were subjected to further testing using API STAPH IDENT 32 Staph (Biomerieux, Marcy l'Etoile, France).

\subsection{DNA extraction and PCR assay}

DNA extracted from S. aureus strains by using the QIAamp DNA Mini kit (Qiagen, Germany, GmbH) with modifications from the manufacturer's recommendations. Briefly, $200 \mu \mathrm{l}$ of the sample suspension was incubated with $10 \mu \mathrm{l}$ of proteinase $\mathrm{K}$ and $200 \mu \mathrm{l}$ of lysis buffer at $56^{\circ} \mathrm{C}$ for $10 \mathrm{~min}$. After incubation, $200 \mu \mathrm{l}$ of $100 \%$ ethanol was added to the lysate. The sample was then washed and centrifuged following the manufacturer's recommendations. Nucleic acid was eluted with $100 \mu \mathrm{l}$ of elution buffer provided in the kit.

\subsection{PCR detection of (coa) gene}

The coa gene was amplified by using two sequences of the primers, Forward primer: 5' CGA GAC CAA GAT TCA ACA AG 3' and reverse primer: 5' AAA GAA AAC CAC TCA CAT CA 3' [10]. Primers were utilized in 25- $\mu 1$ reaction containing $12.5 \mu 1$ of EmeraldAmp Max PCR Master Mix (Takara, Japan), $1 \mu 1$ of each primer of $20 \mathrm{pmol}$ concentration, $4.5 \mu \mathrm{l}$ of water, and $6 \mu \mathrm{l}$ of DNA template. Amplification was conducted in thermal cycler, which was adjusted as follows, an initial denaturation at $94^{\circ} \mathrm{C}$ for 5 min. The cycling proceeded for 30 cycles of denaturation at $94^{\circ} \mathrm{C}$ for $30 \mathrm{sec}$, annealing at $55^{\circ} \mathrm{C}$ for $45 \mathrm{sec}$, and extension at $72^{\circ} \mathrm{C}$ for $45 \mathrm{sec}$ with a step of the final extension at $72^{\circ} \mathrm{C}$ for $10 \mathrm{~min}$.

\subsection{PCR Product analysis}

The PCR reaction mixtures were analyzed by electrophoresis on a $1.5 \%(\mathrm{w} / \mathrm{v})$ agarose gel in the presence of 100- bp DNA ladder (Fermentas Life Science, EU) [11].

\subsection{Coagulase gene typing by RFLP method}

S. aureus strains positive (coa) gene was subjected to restriction fragment length polymorphism. PCR amplified (coa) gene product were digested with BsuRI enzyme,Preparation of restriction master mix according to Thermo FastDigest ${ }^{\circledR}$ BsuRI Cat. No. FD0154 were shown in table (1).

Table 1. Master Mix preparation for BsuRIenzyme

\begin{tabular}{|l|l|}
\hline Component & Volume/reaction \\
\hline 10X FastDigest Green buffer & $2 \mu \mathrm{l}$ \\
\hline BsuRI enzyme & $1 \mu \mathrm{l}$ \\
\hline PCR product & $10 \mu \mathrm{l}$ \\
\hline Water, nuclease -free & $17 \mu \mathrm{l}$ \\
\hline
\end{tabular}

The restricted fragments were separated in $1.5 \%$ agarose gel.

\subsection{Multiplex PCR for enterotoxins}

Primers were utilized in a 50- $\mu 1$ reaction containing $25 \mu \mathrm{l}$ of EmeraldAmp Max PCR Master Mix (Takara, Japan), $1 \mu \mathrm{l}$ of each primer of 20 pmol concentration, $5 \mu \mathrm{l}$ of water, and $10 \mu 1$ of DNA template.

Table 2. Multiplex PCR for enterotoxins

\begin{tabular}{|c|c|c|c|c|c|c|c|c|}
\hline \multirow{2}{*}{$\begin{array}{l}\text { Target } \\
\text { gene }\end{array}$} & \multirow[t]{2}{*}{ Primers sequence } & \multirow{2}{*}{$\begin{array}{l}\text { Amplified } \\
\text { segment } \\
\text { (bp) }\end{array}$} & \multirow{2}{*}{$\begin{array}{l}\text { Primary } \\
\text { denaturation }\end{array}$} & \multicolumn{3}{|c|}{ Amplification (35 cycles) } & \multirow{2}{*}{$\begin{array}{l}\text { Final } \\
\text { extension }\end{array}$} & \multirow[t]{2}{*}{ Reference } \\
\hline & & & & $\begin{array}{l}\text { Secondary } \\
\text { denaturation }\end{array}$ & Annealing & Extension & & \\
\hline \multirow[t]{2}{*}{ Sea } & $\begin{array}{l}\text { GGTTATCAATGTGC } \\
\text { GGGTGG }\end{array}$ & \multirow[t]{2}{*}{102} & \multirow[t]{8}{*}{$\begin{array}{l}94^{\circ} \mathrm{C} \\
5 \mathrm{~min} .\end{array}$} & \multirow[t]{8}{*}{$\begin{array}{l}94^{\circ} \mathrm{C} \\
30 \mathrm{sec}\end{array}$} & \multirow[t]{8}{*}{$\begin{array}{l}50^{\circ} \mathrm{C} \\
45 \mathrm{sec} .\end{array}$} & \multirow[t]{8}{*}{$\begin{array}{l}72^{\circ} \mathrm{C} \\
45 \mathrm{sec} .\end{array}$} & \multirow[t]{8}{*}{$\begin{array}{l}72^{\circ} \mathrm{C} \\
10 \mathrm{~min} .\end{array}$} & \multirow[t]{8}{*}[12]{} \\
\hline & $\begin{array}{l}\text { CGGCACTTTTTTCTC } \\
\text { TTCGG }\end{array}$ & & & & & & & \\
\hline \multirow[t]{2}{*}{$\mathrm{Seb}$} & $\begin{array}{l}\text { GTATGGTGGTGTAA } \\
\text { CTGAGC }\end{array}$ & \multirow[t]{2}{*}{164} & & & & & & \\
\hline & $\begin{array}{l}\text { CCAAATAGTGACGA } \\
\text { GTTAGG }\end{array}$ & & & & & & & \\
\hline \multirow[t]{2}{*}{$\mathrm{Sec}$} & $\begin{array}{l}\text { AGATGAAGTAGTTG } \\
\text { ATGTGTATGG }\end{array}$ & \multirow[t]{2}{*}{451} & & & & & & \\
\hline & $\begin{array}{l}\text { CACACTTTTAGAAT } \\
\text { CAACCG }\end{array}$ & & & & & & & \\
\hline \multirow[t]{2}{*}{ Sed } & $\begin{array}{l}\text { CCAATAATAGGAGA } \\
\text { AAATAAAAG }\end{array}$ & \multirow[t]{2}{*}{278} & & & & & & \\
\hline & ATTGGTATTTTTTTT & & & & & & & \\
\hline
\end{tabular}




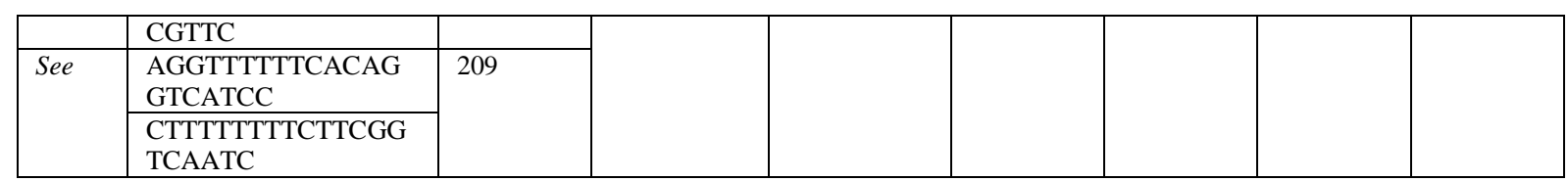

\section{Results}

A number of identified nine $S$. aureus isolates were recovered from 20 imported pork by-products samples with an incidence of $45 \%$, while $18 \mathrm{~S}$. aureus were isolated from local pork by-products (18/30) with an incidence (60\%)respectively, therefore the overall incidence of S. aureus isolates was 27/50 (54\%) .Our study detected coa gene in $17 / 27 \mathrm{~S}$. aureus strains (imported pork by-products, no=6 and local, no=11) with percentage $(62.9 \%)$ as presented in photo (1).

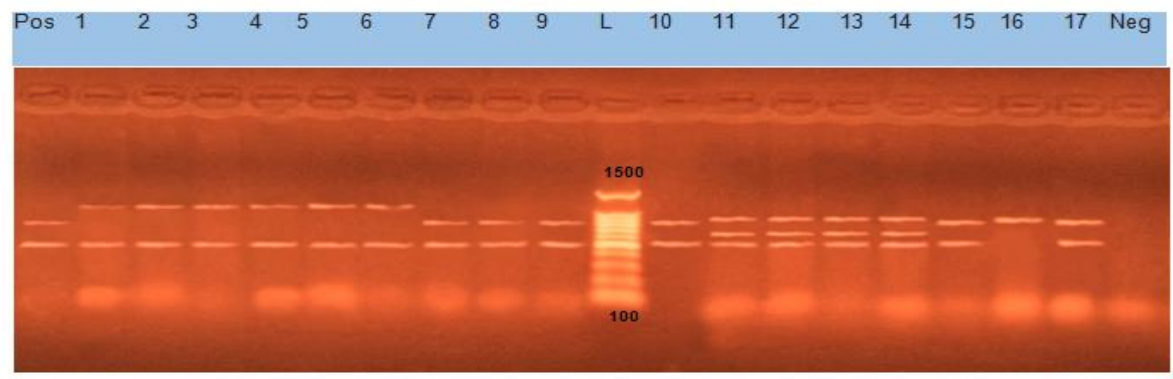

Photo 1: Amplified PCR product of coa gene L: 100bp ladder. Lane Neg: negative control. Lane Pos: positive control. Lanes 1-6: represented imported samples isolates, Lanes (7-10), (11-14), (15-17): represented local samples isolates obtained from factories no 1,2, and 3 respectively. The coa gene PCR products of $17 S$. aureus produced different size fragments which ranged from $491 \mathrm{bp}$ to $1183 \mathrm{bp}$ approximately as explained in the table (3).

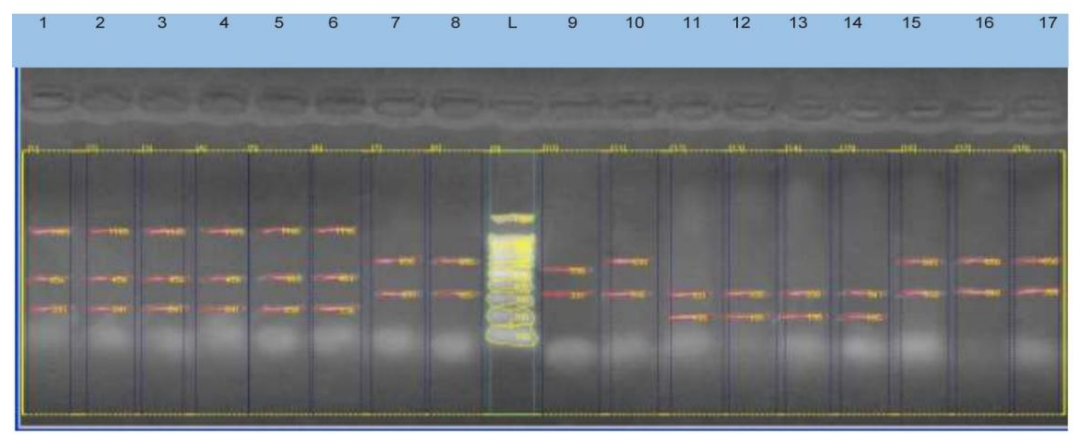

Photo 2. Restricted fragments of coa gene by BsuRIenzyme; Lane L: 100bp ladderLanes1-6: represented imported samples isolates, Lanes (7-10), (11-14), (15-17): represented local samples isolates obtained from factories no 1,2, and 3 respectively. The results of coa gene typing of $S$. aureus strains by RFLP were mentioned in the table (3).

Table 3. PCR product and restricted fragment size of coa gene

\begin{tabular}{|l|l|l|l|l|}
\hline Sample no & Source & PCR product (bp) & Restricted fragments (bp) & Genotype \\
\hline 1 & Imported pork by-products & 498,1164 & $241,454,1175$ \\
\hline 2 & Imported pork by-products & 498,1183 & $241,458,1185$ \\
\hline 3 & Imported pork by-products & 500,1164 & $241,458,1175$ \\
\hline 4 & Imported pork by-products & 498,1183 & $241,458,1175$ \\
\hline 5 & Imported pork by-products & 498,1183 & $238,465,1196$ \\
\hline 6 & Imported pork by-products & 491,1178 & $236,469,1196$ \\
\hline 7 & Local pork by-products (LF1) & 496,861 & 338,656 \\
\hline 8 & Local pork by-products (LF1) & 500,861 & 335,650 \\
\hline 9 & Local pork by-products (LF1) & 496,840 & 331,538 \\
\hline 10 & Local pork by-products (LF1) & 504,858 & 338,650 \\
\hline 11 & Local pork by-products (LF2) & $491,647,990$ & 195,331 \\
\hline 12 & Local pork by-products (LF2) & $496,648,990$ & 195,338 \\
\hline 13 & Local pork by-products (LF2) & $496,654,990$ & 198,338 \\
\hline 14 & Local pork by-products (LF2) & $491,654,990$ & 195,341 \\
\hline 15 & Local pork by-products (LF3) & 504,850 & 338,643 \\
\hline 16 & Local pork by-products (LF3) & 917 & 348,650 \\
\hline 17 & Local pork by-products (LF3) & 514,861 & 355,656 \\
\hline
\end{tabular}

LF1=Local factory (1)LF 2= Local factory (2)LF 3= Local factory (3)

Table (3) showed that, samples from (1 to 6), (7 to 10), (11to14), (15to 17) are the same respectively. 


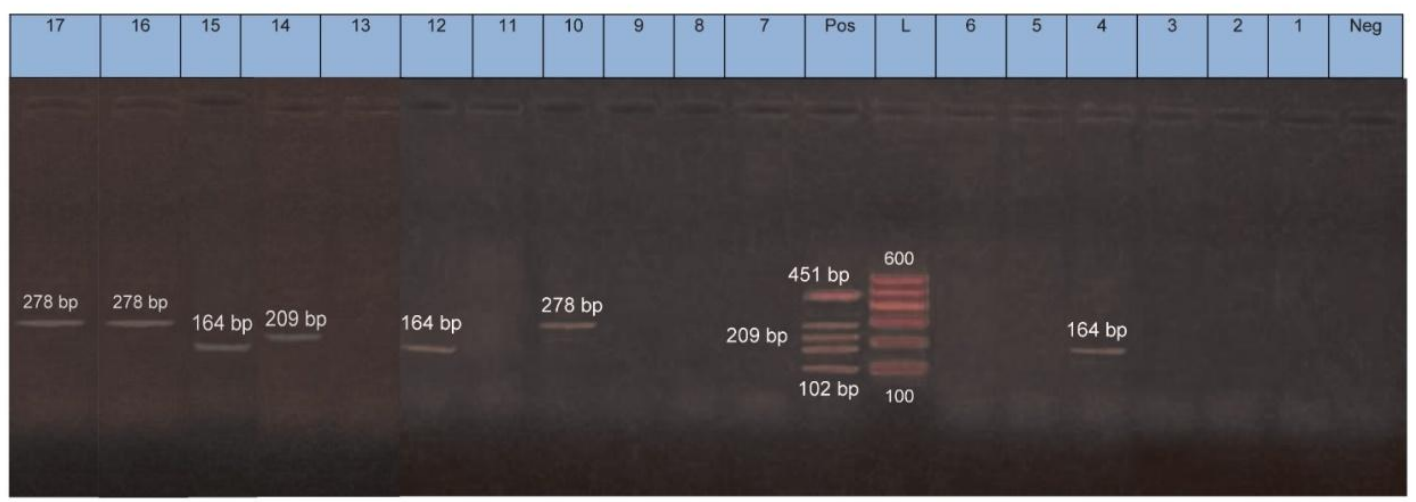

Photo 3: Multiplex PCR of enterotoxins; Lane L: 100bp ladder. Lane Neg: negative control. Lane Pos: positive control.Lanes4,12,15: realized Seb. Lanes 10,16,17realized Sedand Lane 14: realized Seb.

The 17 coagulase positive strains were screened for the presence of enterotoxin genes ( Sea, Seb, Sec, Sed, and See). The results obtained from (Photo 3) showed that there are 7 strains harbored enterotoxin genes, each strain contains one gene by a ratio $(41 \%)$ and by total isolated strains $7 / 27(26 \%)$. One strain was belonged to the imported samples, harboring $\operatorname{Seb}(164 \mathrm{bp})$ and the other 6 were isolated from the local ones, 3 carry Sed (278bp), two carry Seb, and one carries See (209bp).

\section{Discussion}

Using culture, biochemical and API methods, the present study identified a number of 27 S. aureus isolates out of 50 imported and locally manufactured pork by-products samples collected from great Cairo territory, with an incidence of 54\%.This high recovery ratio was found in other previous studies as, Among 155 'Nham' (a traditional Thai fermented pork product) samples tested, 39.35\% of the samples were positive for S. aureus [13], another study inOklahoma 43/99 (43.3\%)[14].

Our study detected coa gene in 17 / 27 S. aureus isolates (imported pork by-products, no=6 and local, no $=11)$ with percentage $(62.9 \%)$ as presented in photo $(1)$. This percentage was lower than the previous reported percentage $80.5 \%$ [15]. The amplified coa gene PCR products of $17 \mathrm{~S}$. aureus strains produced different size fragments which ranged from 195 bp to $1196 \mathrm{bp}$ approximately. A near similar range of PCR amplicon products has also been stated by other researchers, 579 to 1442 bp [16], 484 to 1080 bp [17] and 500 to $1400 \mathrm{bp}$ [15]. Instead of the present perception for coa amplicons in the present examination, only one type of amplicon was obtained i.e. 500 bp $S$. aureus subclinical mastitis strains in Nigeria[18]. This variance may be attributed to a C-terminal region of The coagulase gene, which composed of 81-bp tandem repeated units, each encode 27amino acid residues, comprising four, five, six, seven and eight units of the 81-tandem repeat, therefore, the size of 3 'region of the coa gene is variable [19].

According to table (3), and photo (2): The PCR products of coa gene were subjected to restriction digestion using RFLP with BsuRI enzyme. The obtained results represented 4 different restriction patterns (I, II, III, and IV). This variation in restriction patterns was referred to the variable number tandem repeat (VNTRs) present in each isolates. The present study emphasizes the genotypic variation among different S.aureus isolates discussed in many previous reports. Pulsed-field gel electrophoresis patterns showed a wider variety (discriminatory index 0.83) among 94 strains of $S$. aureus isolated from cow's milk, raw cheese, and a milking machine in 12 dairy farms in northeast Brazil [20]. Another study in Iran; fifty eight $S$. aureus isolates were recovered from milk samples of cows with clinical and subclinical mastitis were analyzed using RFLP of coa gene with restriction endonuclease HaeIII, resulting in nine patterns [21]. There is a higher coa gene polymorphism of $S$. aureus isolated from native cattle breed (eight coa types) as compared to that in $\mathrm{H}-\mathrm{F}$ crossbred cattle (three coa types) with the Alu restriction endonuclease [22]. As appeared in table (3), the $S$. aureus coa gene patterns were similar according to the source of samples, this finding in harmony with that study conducted in Iran [23], and proved that, there is no variation between the coa genes from the same source.

Due to their public health importance the 17 positive coa gene isolates were screened for the presence of enterotoxigenic genes (A-E). The photo (3) PCR analysis showed amplification of one gene type in 7 isolates out of total 27 (25.9\%), distributed as one isolate from imported samples, carrying Seb., the other six present in the local ones, 3 carry Sed, two carry Seb, and one carries See. The apparently low presence of enterotoxin carrying genes in $S$. aureus isolates is not a surprise as other investigations seem to illustrate these data;one isolate $(0.9 \%)$ from pork was positive for enterotoxin gene [14],12.8\%[24], 18\% [25], and15\%[26]. Although the classical Staph Enterotoxines (SE) are considered to be major etiological factors in Staphylococcal food 
poisoning (SFP), the newly described $S E$ or $S E$ like genes (seg to ser, and seu) were more frequently detected than the classical SE genes [27]. Also the storage of pork meat and pork byproducts in low temperature plays an important role not only the decreasing enterotoxigenic $S$. aureus detection, but also the total $S$. aureus isolation[13].

\section{Conclusion}

The ready to eat pork by-products, either imported or locally manufactured are seem to be a source of coagulase positive $S$. aureus (CPS)strains which play an important role in the pathogenicity and invasiveness. Detection of coa gene is the principal standard for the identification of CPS strains, the restriction fragment length polymorphism (RFLP) is a more useful tool to detect polymorphism in (coa) gene for local epidemiologic purposes.Finally, the presence of enterotoxins genes in about $26 \%$ of isolates suggests the risk of food poisoning associated with the retail pork products and affirm the need of improving food handlers guidelines, and the obligatory use of cooled display as a public health establishment.

\section{References}

[1]. F.A.Waldvogel,. Staphylococcus aureus (including staphylococcal toxic shock). [In Principles and practice of infectious diseases. G.L. Mandell, J.E. Bennett, and R. Dolin, editors. Churchill Livingstone. Philadelphia, Pennsylvania, USA.]2000, 20692092.

[2]. S. Defres, C. Marwick, and D. Nathwani, 2009. MRSA as a cause of lung infection, including airway infection, community acquired pneumonia and hospital-acquired pneumonia. European Respiratory Journal, 34 (6): 1470-1476.

[3]. B. Shopsin, M. Gomez, M. Waddington, M. Riehman, and B. N. Kreiswirth, Use of Coagulase Gene (coa) Repeat Region Nucleotide Sequences for Typing of Methicillin-Resistant Staphylococcus aureus Strains. Journal Of Clinical Microbiology, 2000, 3453-3456.

[4]. A.G. Cheng, M. Mcadow, H.K. Kim, T. Bae, D.M. Missiakas, and O. Schneewind, Contribution of coagulases towards Staphylococcus aureus disease and protective immunity. Plos pathogen, 6 (8), 2010, 1-17.

[5]. O. Aslantas, C. Demir, H. Turutoglu, Z. Cantekin, Y. Ergun, and G. Dogruer, Coagulase gene polymorphism of Staphylococcus aureus isolated from subclinical bovine mastitis. Turkish Journal Veterinary Animal Science, 31, 2007, 253-257.

[6]. M. Á. Argudín, C. M. María, and R. R. María, Food poisoning and Staphylococcus aureus enterotoxins. Toxins (Basel). 2(7), 2010, 1751-1773.

[7]. S. Johler, F. Layer, and R. Stephan, Comparison of virulence and antibiotic resistance genes of food poisoning outbreak isolates of Staphylococcus aureus with isolates obtained from bovine mastitis milk and pig carcasses. Journal Food Protection, 74(11), 2011, 1852-1859.

[8]. J.M. Soriano, H. Rico, J.C. Moltó, J. Manes, Microbial evaluation of Spanish potato omelette and cooked meat samples in University restaurants. Journal Food Protection, 63, 2000, 1273-1276.

[9]. G. Mauriello, A. Casaburi, G. Blaiotta, and F. Villani, Isolation and technological properties of coagulase negative staphylococci from fermented sausages of Southern Italy. Meat Science 67, 2004, 149-158.

[10]. N.Y. Omar, H. A. Abdel Salam, A. H. Reem, and E. El Khayat,. Molecular typing of methicillin resistant Staphylococcus aureus clinical isolates on the basis of protein a and coagulase gene polymorphisms. International Journal of Microbiology, 2014, 2014, 111.

[11]. J. Sambrook, E.F. Fritsch, and T. Maniatis,. Purification of closed circular DNA by equilibrium centrifugation in Cs-Clethidium bromide gradients. [In: Molecular Cloning: 1989, 260-280, A Laboratory Manual, New York, CSH Laboratory].

[12]. M. Mehrotra, W. Gehua, and M. J. Wendy, Multiplexpcr for detection of genes for Staphylococcus aureus enterotoxins, exfoliative toxins, toxic shock syndrome toxin 1, and methicillin resistance. Journal Clinical Microbiology, 38(3), 2000, $1032-1035$.

[13]. N. Chokesajjawatee, S. Pornaem, Y.G. Zo, S. Kamdee, P. Luxananil, S. Wanasen, and R.Valyasevi,. Incidence of Staphylococcus aureus and associated risk factors in Nham, a Thai fermented pork product. Food Microbiology, 26 (5), 2009, 547-51.

[14]. L.S. Abdalrahman, W. Harrington, and K. F. Mohamed, Staphylococcus aureus is more prevalent in retail beef livers than in pork and other beef cuts. Pathogens, 4 (2), 2015, 182-198.

[15]. M. Karahan, and B. Cetinkaya, Coagulase gene polymorphisms detected by PCR in Staphylococcus aureus isolated from subclinical bovine mastitis in Turkey. Veterinary Journal, 174 (2), 2006, 428-431.

[16]. E. R. Da Silva, and N. Da Silva, Coagulase gene typing of Staphylococcus aureus isolated from cows with mastitis in southeastern Brazil. Canadian Journal Veterinary Research, 69(4), 2005, 260-264.

[17]. E.R. Da Silva, J.U. Boechat, and N. Da Silva, Coagulase gene polymorphism of Staphylococcus aureus isolated from goat mastitis in Brazilian dairy herds. Lett Appllied Microbiology, 42 (1), 2006, 30-4.

[18]. A.B. Suleiman, J.K.P. Kwaga, V. J. Umoh, , E.C. Okolocha, M. Muhammed, C. Lammler, S. J. Shaibu, O. Akineden, and R. Weiss, Macro-restriction analysis of Staphylococcus aureus isolated from subclinical bovine mastitis in Nigeria. African Journal of Microbiology Research 6(33), 2012, 6270-6274.

[19]. I. Janwithayanuchit, N. Somying, P. Porntip, and R. Watcharin,. Epidemiologic Study of methicillin-resistant Staphylococcus aureus by Coagulase Gene Polymorphism. Science Asia 32, 2006, 127-132.

[20]. V.M. Silveira-Filho, I.S. Luz, A.P. Campos, W.M. Silva, M.P. Barros, E.S. Medeiros, M.F. Freitas, R.A. Mota, M. J. Sena, and T.C. Leal-Balbino, Antibiotic resistance and molecular analysis of Staphylococcus aureus isolated from cow's milk and dairy products in northeast Brazil. Journal Food Protection, 77(4), 2014, 583-591.

[21]. H.D. Saei, M. Ahmadi, K. Mardani, and R.A. Batavani, Molecular typing of Staphylococcus aureus isolated from bovine mastitis based on polymorphism of the coagulase gene in the north west of Iran. Veterinary Microbiology, 137 (1-2), 2009, $202-206$.

[22]. T. Bhati, , N. Prerna, A. M. Irfan, K .Sh. Sandeep, Y. Rahul, and K. K. Anil, PCR-RFLP of Staphylococcus aureus Coagulase Gene Isolated from Bovine Subclinical Mastitis. Journal of Pure and Applied Microbiology, 8 (6), 2014, 4711-4714.

[23]. A. A. Dehkordi, T. Elahe, T. Forough, K. Faham, M. S. Manouchehr, and M. Hossein, Molecular Typing of Staphylococcus aureus strains from Iranian raw milk and dairy products by coagulase gene polymorphisms. Advanced Studies in Biology,7 (4), 2015,169 $-177$.

[24]. D. Hao,X. Xing,G. Li,X. Wang, M. Zhang, W. Zhang,X. Xia, and J. Meng, Prevalence, toxin gene profiles, and antimicrobial resistance of Staphylococcus aureus isolated from quick-frozen dumplings. Journal Food Protection, 78(1), 2015, 218-223. 
[25]. C.P.Young, M.M.O'Donoghue, J. Ho, and M.V. Boost,High levels of Staphylococcus aureus contamination in Chinese-style roast pork. Foodborne Pathog Dis, 11(7), 2014, 552-554.

[26]. S. Pu, F. Wang, and B. Ge, Characterization of toxin genes and antimicrobial susceptibility of Staphylococcus aureus isolates from Louisiana retail meats. Foodborne Pathogen Disease, 8(2), 2011, 299-306.

[27]. S.Y. Hwang, S.H. Kim, E.J. Jang, N.H. Kwon, Y.K. Park, H.C. Koo, W.K. Jung, J.M. Kim, and Y.H. Park, Novel multiplex PCR for the detection of the Staphylococcus aureus superantigen and its application to raw meat isolates in Korea. International Journal Food Microbiology. 10;117(1), 2007, 99-105. 